\title{
Growing up between two worlds: a portrait of second-generation American a multimedia project
}

\author{
Dalia Ahmed Elsaid
}

Follow this and additional works at: https://researchrepository.wvu.edu/etd

\section{Recommended Citation}

Elsaid, Dalia Ahmed, "Growing up between two worlds: a portrait of second-generation American a multimedia project" (2018). Graduate Theses, Dissertations, and Problem Reports. 3969.

https://researchrepository.wvu.edu/etd/3969

This Problem/Project Report is protected by copyright and/or related rights. It has been brought to you by the The Research Repository @WVU with permission from the rights-holder(s). You are free to use this Problem/Project Report in any way that is permitted by the copyright and related rights legislation that applies to your use. For other uses you must obtain permission from the rights-holder(s) directly, unless additional rights are indicated by a Creative Commons license in the record and/ or on the work itself. This Problem/Project Report has been accepted for inclusion in WVU Graduate Theses, Dissertations, and Problem Reports collection by an authorized administrator of The Research Repository @ WVU. For more information, please contact researchrepository@mail.wvu.edu. 
Growing up between two worlds:

A portrait of second-generation Americans

A Multimedia Project

\section{Dalia Elsaid}

A project submitted to The Reed College of Media at West Virginia University as a partial fulfillment of the requirements for the degree of

Master of Science

in Journalism

Approved by

Lois Raimondo, M.A., Committee Chair

Mary Kay McFarland, M.A.

Bob Britten, Ph.D.

Karen Laing, Ed.D.

Morgantown, West Virginia

2018

Keywords: Second-generation, Home, Identity, Stereotypes, Representation, Culture, Assimilation, Immigration, West Virginia, Multimedia

Copyright 2018 Dalia Elsaid 


\begin{abstract}
Growing up between two worlds:

A portrait of second-generation Americans

A Multimedia Project
\end{abstract}

\title{
by Dalia Elsaid
}

This professional project is a multimedia project focusing on stories of three second-generation Americans in West Virginia. The project is disseminated using a website. It includes content curated by the project author (photos, videos, written stories, data visualization) and information selected by the participants themselves. The content will add to the information available on different cultural communities in West Virginia in general, and on second-generation Americans in particular. It is hoped the project, through its portrayals of these individuals and their immigrant families, will help to dispel and counter some of the stereotypical depictions of immigrants. With this goal in mind, this project attempts to communicate a more complex and nuanced portrait of these individuals and present their stories in a way that differs from the typically immigrants' lives portrayed by the media. 


\section{Acknowledgements}

Thank you to everyone who helped me complete this project. Foremost, I would like to express my sincere gratitude to my advisor Prof. Lois Raimondo for her continuous support, her guidance, motivation, enthusiasm, and immense knowledge. I could not have imagined having a better advisor and mentor for my master's degree.

My sincere thanks also goes to Prof. Mary McFarland. It was under her tutelage that I developed a focus and became interested in multimedia storytelling. She provided me with direction, technical support and became more of a mentor, than a professor.

I would also like to thank the rest of my committee, Prof. Bob Britten and Prof. Karen Laing for their encouragement and insightful comments. Their expertise, understanding, and patience added considerably to my graduate experience.

Obviously, this project wouldn't have come to light without the families who opened their houses and hearts to me. They reminded me of what's really important and showed me that every story, every perspective, and every experience matter equally and infinitely. I am profoundly indebted for the opportunity they gave me.

Last but definitely not least, I thank my family for the support they provided me through my entire life: my mum for her constant love and immeasurable sacrifice, my dad for perspective

and the will to strive. I would like to deeply thank my steadfast husband, Osama, for his enduring love, for believing in me, and for always standing by my side.

The last word goes for Jumana, my baby girl, who has become the light of our life for the last month and who has given me the extra strength and motivation to get things done before we welcome her to the world. This project is dedicated to her and the loving memory of my best friend Dalia El Sonbaty. Forever in my heart! 


\section{Table of Contents}

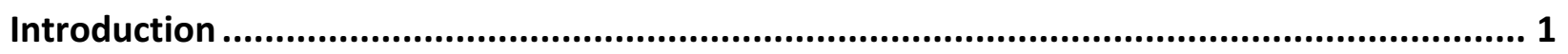

Background: A Look at West Virginia's Immigrant Past...................................................... 5

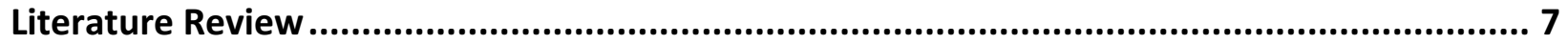

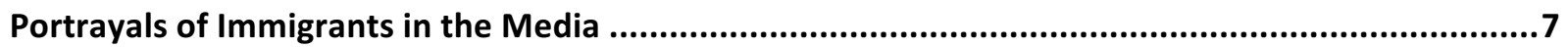

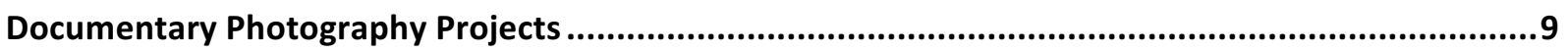

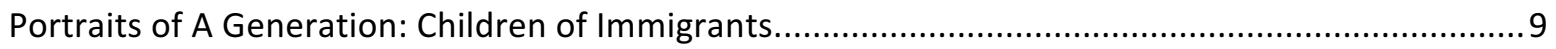

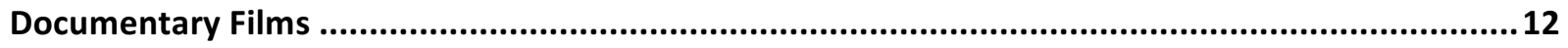

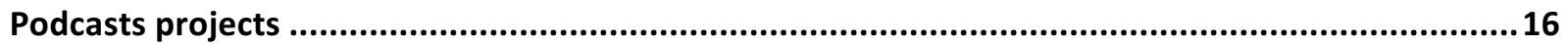

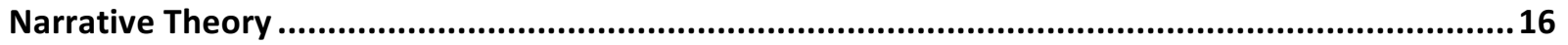

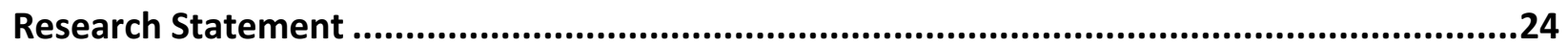

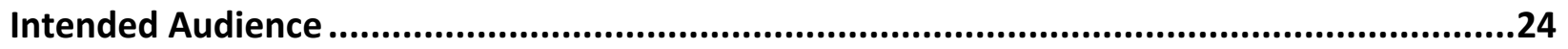

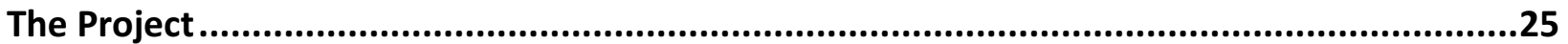

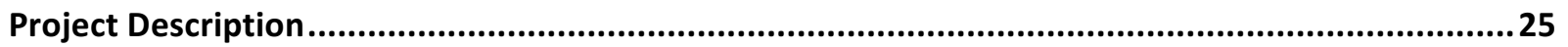

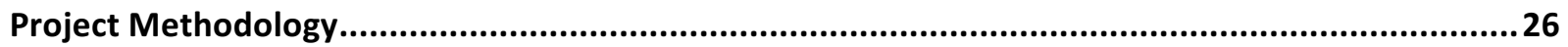

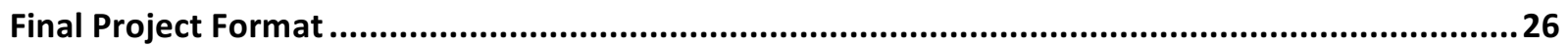

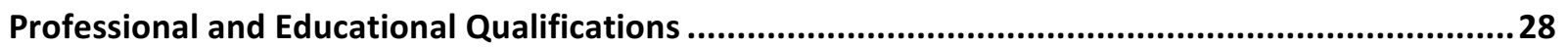

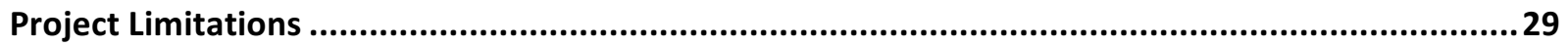

Timeline

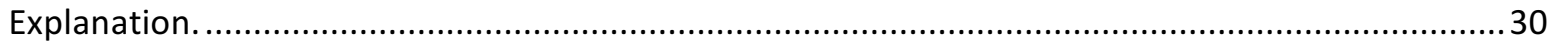

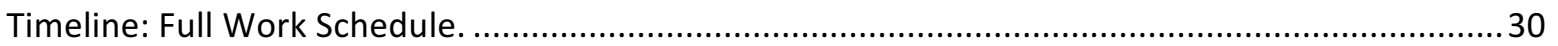

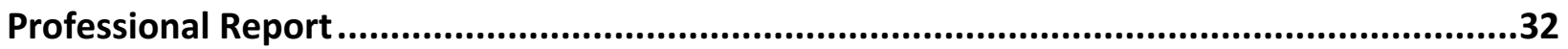

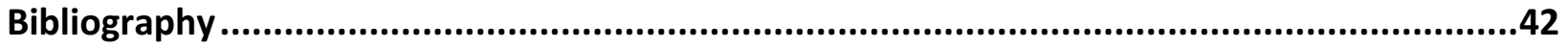

Appendix I: Interview Core Questions ............................................................................48

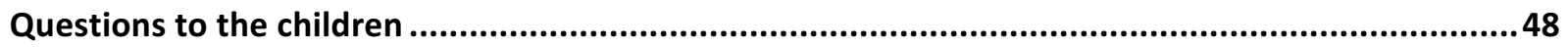

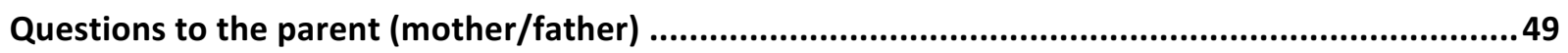

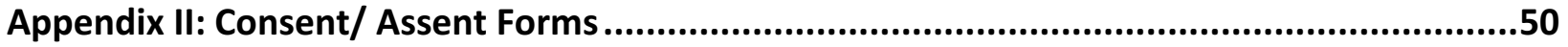

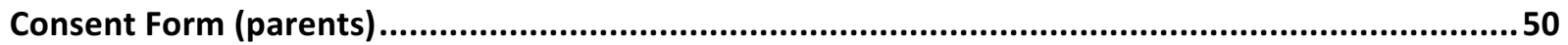

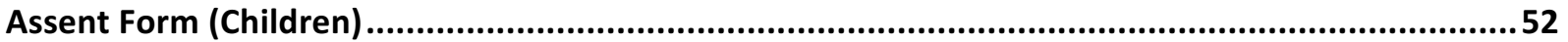




\section{Introduction}

Immigrants have been a part of American history for centuries, with multiple generations of people coming to the United States from all over the world to create new lives for themselves and their families. The data provided by the Migration Policy Institute denotes that the United States attracts the largest number of immigrants in the world, who join the fabric of the American society through different avenues (Bush et al. 2009).

The term "immigrant" used here (also known as the foreign born) refers to people residing in the United States who were not U.S. citizens at birth. This population includes naturalized citizens, lawful permanent residents (LPRs), certain legal nonimmigrants (e.g., persons on student or work visas), those admitted under refugee or asylum status, and persons illegally residing in the United States (Zong \& Batalova, 2016). Immigrants percentage and reasons for immigration have differed throughout the years. In 1850, there were 2.2 million immigrants in the United States, representing nearly 10 percent of the population (Gibson and Jung, 2005). That percentage peaked at 14.8 percent in 1890 , mainly due to high levels of immigration from Europe escaping famine, religious persecution, and political conflicts. Restrictive immigration legislation in 1921 and 1924, coupled with the great depression and World War II, led to a sharp drop in new arrivals. As a result, the foreign-born share steadily declined between the 1930s and 1970s, reaching a record low of approximately 5 percent in 1970. Since 1970, the share and number of immigrants have increased rapidly, mainly as a result of large-scale immigration from Latin America and Asia made possible by the abolishment of national-origin admission quotas by Congress in 1965. According to the 2016 Current Population Survey (CPS), immigrants and their U.S.-born children now number approximately 84.3 million people, or 27 percent of the overall U.S. population (Zong \& Batalova, 2017). 
For several decades, scholars of immigrant adaptation have been interested in studying the U.S.-born children of immigrants, commonly referred to as second-generation immigrants. The scholarship on immigrant adaptation has defined the immigrant second-generation as nativeborn residents who have at least one foreign-born parent (Borjas, 1999; Portes and Rumbaut, 2001). As reported by the Migration Policy Institute, the number of second-generation immigrant children has grown steadily since 1990 . Between 2000 and 2015, this population grew 52 percent (from 10.4 million to 15.8 million). Currently, one in four ( 25 percent) school-aged children is foreign-born or the child of foreign-born parents, a proportion that is higher than it has been in several generations (Zong \& Batalova, 2017).

In discussions about children of immigrants, the aforementioned numbers and statistics are certainly important tools but there is another important ingredient in that stew: Experience. There is no room for that on those official census forms. They need to be complemented by real life stories and experiences of those defined and measured in these figures. Experience is a cover-all term for the various modes through which a person knows and constructs a reality. As Yi-Fu Tuan (2014) puts it, "Intimate experiences lie buried in our innermost being so that not only do we lack the words to give them form, but often we are not even aware of them" (p. 136). A human life begins at birth and ends in death: it's a one-way journey. Human time is biased in favor of the future. That latter word is key to why the parents of these children made the choice of moving to another country. Those individuals are more than numbers, more than the reports that analyze their educational attainment and economic standing, and this is why this project will attempt to put a face to second-generation Americans in one small portion of the U.S.: Morgantown city in the state of West Virginia. 
The idea of this project was first developed in the "International Media" class by Prof. Lois Raimondo during the 2017 spring semester. It was shaped by conversations I've had with second-generation Americans, age 7 to 15, and their mothers. The families talked about the daily details that compound their lives. The children reflected on self-identification, a concept that gains another dimension when you navigate two cultures at once. The mothers addressed the challenges as well as the perks of raising their children in a cultural upbringing different than the one they had. The richness and range of their human experiences led to the expansion of this assignment to a documentary project to explore the diverse layers this topic unfolds.

Documentary projects have been used to traverse layers of culture, geography, and time. They have been proven an invaluable method of exploration. As explained by Maccarone (2010), documentary projects represent an attempt to tell a true story, often from a particular perspective, trying to elicit a feeling similar to the real event or person, relying little on the obvious manipulation of images and sound, yet also displaying some degree of artistry. Elaborating on the above, in this project, a documentary narrative exploring the faces of second-generation Americans in Morgantown, WV, will be composed using multimedia tools such as photographs and video. The use of documentary photography and videos will allow this project to examine the stories of second-generation Americans from different descent in-depth, rather than simply including their words as might occur in a typical news story in an attempt to achieve a more coherent understanding of children of immigrants who were born in a country different than their parents'.

This project significance centers around the current time we live in. We're at a certain point in history where immigration is a hot topic that not only affects national policy, but also Americans' perception of other nationalities, races, and ethnicities living here, and vice versa 
(Krogstad, 2015). Previous studies have indicated that people's attitude towards immigrants hinges on their beliefs about immigration, which have been shown to be often biased (Blinder, 2015; Citrin and Sides, 2008; IpsosMori, 2014). Throughout the last decade, the tide of people moving across the world, be they immigrants or refugees, has sparked concern in Australia, Europe and the United States. In particular, the ethnic, linguistic and cultural background of migrants has triggered intense debates over the benefits and the costs of growing diversity and the risk of open borders to national identity (Connor, 2016). As a result, political parties and candidates with a strong anti-immigration stance have gained support in the last few years, such as the Front National in France, or Donald Trump in the United States (Wike, 2017). This was also reflected on how people in host countries feel about immigrants. In recent years, the United States and many European countries have witnessed a surge in anti-immigrant sentiment (Sniderman et al., 2004), and a large proportion of the population views immigration as one of the most pressing issues facing their country. For instance, more than three quarters of British citizens wanted to reduce immigration in 2015 (Blinder, 2015), while more than forty percent of Americans reported being very dissatisfied with the level of immigration in the U.S. in January 2016 (Gallup, 2016). It is therefore particularly important to understand whether people would change their attitude towards immigrants if they receive accurate information about immigration and a realistic depiction of their stories.

Without learning about other cultures, we have no hope in understanding what the world is really like. Yi-Fu Tuan (2014) explains that evaluations and judgements tend to be clichés. The fleeting intimacies of direct experience and the true quality of a place often escape notice because the head is packed with shopworn ideas (p.146). Alone, one's thoughts and perceptions wander freely. In the presence of others, they are reformulated. 


\section{Background: A Look at West Virginia's Immigrant Past}

The Appalachian region (covering all of West Virginia, parts of New York, Pennsylvania, Ohio, Maryland, Virginia, the Carolinas, Tennessee, Kentucky, Georgia, Alabama, and Mississippi) has long been considered a predominantly white section of the United States, particularly in comparison with the rest of the country (Pollard, 2004). A map created by Randy Olson can help us understand where West Virginia particularly stands nationally in terms of diversity (Narula, 2014). His visualization map shows racial diversity across the United States' nearly 3,000 counties. Like the nation's population, the results were mixed. Vermont was found to be the least diverse state in the nation, while the least diverse county, according to Olson's calculations, was Tucker county in West Virginia with 100 percent white population.

However, this broad generalization fails to take into account the immense diversity and subcultures of some of the most seemingly homogenous places, particularly those in rural America. Fortunately, a growing body of literature on the topic of race and ethnicity in the region is developing. Since 1990, Appalachia has become more diverse as racial and ethnic minorities have constituted nearly half the region's population growth through 2000 (Pollard, 2004). Diversity exists here — whether socioeconomic, religious, cultural, racial, or in national heritage.

West Virginia is home to a rich diversity of cultures and communities, representing people from all around the world who have found their way to this Appalachian state. According to the 2017 State Physician Workforce Data report, one in three of the active physicians in West Virginia is a foreign medical school graduate (Association of American Medical Colleges, 2017). The state has also witnessed a rise in foreign-cuisine restaurants in places like Morgantown, third largest city in West Virginia, ranking in the upper quartile for population density and diversity index when compared to the other cities, towns and census designated places in West Virginia 
(Data USA, n.d.). Many Middle Eastern, Indian, and Chinese restaurants have seen success and are still in business due to the many international students.

To varying degrees, many of these communities have assimilated into mainstream America, but most of them have also found ways to retain their cultural identity and heritage, including folk art, music and dance, food, religious customs, and family traditions. The presence of these communities and their willingness to share their traditions is a valuable asset to cultural life in West Virginia and a testament to the fact that there is not one story or voice of West Virginia.

West Virginia population stood at 1.8 million for the year 2016 (Migration Policy Institute, 2017). Foreign born residents represented 1.7 percent of that population. These numbers are reflected on the number of second-generation Americans (born to at least one immigrant parents) in the Mountain state. Children with one or more foreign-born parents accounted for 2.8 percent of the total number of children under 18 in the state. 


\section{Literature Review}

\section{Portrayals of Immigrants in the Media}

A report issued by the Opportunity Agenda, a non-profit social justice communication lab, conveyed that in a world influenced by popular culture, experts argue that how people are portrayed in the media can shape perceptions-often in more negative than positive ways (Power of POP: Media Analysis of Representations of Immigrants in Popular TV Shows, 2017). The report analyzed storylines associated with immigration and immigrants within popular television programs during the April 2014 to June 2016 television seasons. The findings indicated that a significant portion of storylines tied to immigration or immigrants centered on some form of unlawful activity including murder, human trafficking, and drug dealing. In a racial and ethnic breakdown of those storylines, 50 percent of Latino immigrant characters were represented in an unlawful act and 38 percent were depicted as incarcerated, 33 percent of Black immigrants and 25 percent of Middle-Eastern immigrants were depicted as incarcerated, while only 9 percent of white immigrants were shown to commit an unlawful act (Tukachinsky, Mastro \& Yarchi, 2015).

The report noted that popular culture can help bring us together, or it can further drive us apart. Unfortunately, the report tells us that television depictions are contributing more to division and discrimination right now than to unity and understanding. Those depictions too often deepen stereotypes, and make bias worse, instead of better. These stereotypes don't come out of nowhere: they are drilled into people's heads over decades through movies, television, and skewed news stories. Other findings of the report conveyed that popular culture is one of the major arenas that determines a group's “outsider” status. Mainstream media, especially film and television, are a fascinating barometer of Americans' ongoing anxieties towards immigrants. 
American actor of Indian descent Aziz Ansari once joked that white people must be excited about movies all the time. "When Slumdog Millionaire came out, I was excited," he said. "It featured people that kinda look like me." When you're not used to seeing people who look like you or act like you on screen, finding a character who speaks to you is a revelatory moment (Saxena, 2017). This idea even prompted Netflix, one of the biggest American entertainment companies, to capture that feeling. Netflix started \#FirstTimeISawMe, a hashtag and video series about representation in entertainment (White, 2017). They sat down with different actors to speak about the characters that inspired them. People were encouraged to share their thoughts online about the first time they felt seen by media, and sometimes about how media still has a long way to go before they could feel represented. Many also pointed out that even if their demographic was represented, the characters were often written as sloppy stereotypes, and didn't do much to help them feel accepted.

The U.S. 2016 election season, with Donald Trump's discussion of walls and bans, further brought immigration issues into public consciousness. More recently, president Trump revived his calls for a wall along the U.S.-Mexico border and a travel ban targeting certain countries after an attack on a mosque in Egypt left at least 235 people dead in November 2017. In a tweet announcing an upcoming phone call with Egyptian President Abdel Fattah El-Sisi, Trump lamented the terrorist attack and took that chance to remind everyone of his plans to curb immigration, "We have to get TOUGHER AND SMARTER than ever before, and we will," said Trump in his tweet. "Need the WALL, need the BAN! God bless the people of Egypt."

And although this is a debate about immigrants, immigrants and their families are largely not given a voice in it. The glaring absence of true representation in movies, TV shows, news stories, media projects, or even cartoons, enhances the feeling of being an outlier, that your story 
is too specific to expect any widespread representation (Tukachinsky et al., 2015). However, some documentary projects in the U.S. attempted to give a voice and represent immigrants of all generations. There are many differing definitions of documentary, whether the documentary is comprised of film, of still photographs, or of a combination of both. The definitions proposed by Tremain (2000) and Maccarone (2010) are only a few of the definitions among many. However, there are common elements that appear among the definitions. It is generally agreed that all documentaries should be truthful (Light, 2000), as well as contain images that can stand on their own, separate from the documentary as a whole (Mark, 1990). These projects became a resource for initiating conversations about diversity and inclusion and a call of action urging all leaders to strive to create more inclusive communities. The projects differed in the approach they used to convey immigrants' stories and get their voices heard. Some of them came in the form of still pictures, films, video profiles, and even podcasts. This project will strive to follow the examples set by previous documentaries, while creating a story that is unique to particularly secondgeneration Americans in Morgantown, WV, in the hope of creating a stage for warm human encounters and opening up the conversation not only on a local scale, but also globally. After all, it is the job of journalists, storytellers, and content creators to create safe spaces for these individuals to tell their own stories (Heberle \& Morgado, 2016). In the next section, we will explore some of these projects that fall into three main areas: documentary photography, documentary films, and podcasts.

\section{Documentary Photography Projects}

Portraits of A Generation: Children of Immigrants. Quetzal Maucci is an Argentinian- and Peruvian-American documentary photographer focusing on human rights and activism. This photographer brings the stories of immigrant children to light. She began to 
photograph these children and document their stories. They came from Argentina, India, Italy and Poland, but their stories had a common theme: they struggled with their identity. Over time, Maucci turned this into a project called "Children of immigrants" that was featured in the New York Times (2012). Maucci's website contains pictures of her subjects in different settings, black and white portraits and quotes. This combination provides an in-depth look at their lives and lend each one of them a voice to tell his/her own story.

One of Maucci's subjects is Sruti Swaminathan. The 22-year-old Indian American said she was embarrassed to even take Indian food to school, and opted for pizza and sandwiches in an attempt to embrace the American culture. In an interview to Public Radio International (PRI), Maucci revealed that she shared with her subject the same feeling of shame about their cultures (Jaafari \& Kulkarni, 2014). "I think what struck me is that everyone really resonated with it," she said. "I can see that this can connect to so many people."

Visualizing Race, Identity, and Change. For its $125^{\text {th }}$ anniversary issue, National Geographic looked at the changing face of America with portraits of multiracial families in an article by Lise Funderburg, with portraits by German photographer Martin Schoeller. Talking about why she decided to tackle that issue, Funderburg (2013) said that in many ways race is about difference and how those differences are codified through language, categories, boxes, segmentation, and even the implicit sorting that goes on in our heads in terms of the way we label others and even ourselves.

Her idea was complemented by Schoeller's portraits that allow us to dive beyond the surface into the deeply nuanced issues of racial ambiguity. They show the limitations around our current categories when talking about race in America which is no longer so black and white. These images end up celebrating the beauty of multiracial diversity. Schoeller's portraits are 
striking in their simplicity, allowing viewers to look into the eyes of those people. The presentation is also visually compelling.

The Hapa project. The Hapa project is a multiracial identity project created by artist Kip Fulbeck. The project embodies a range of mediums, including a published book, traveling photographic exhibition, satellite community presentations, and online communities. Fulbeck (2006) began his project in 2001, traveling the country photographing over 1200 volunteer subjects who self-identified as hapa (defined for the project as mixed ethnic heritage with partial roots in asian and/or pacific islander ancestry). The project consists of 1200 portraits. Each individual was photographed in a similar minimalist style (directly head-on, unclothed from the shoulders up, and without jewelry, glasses, excess make-up, or purposeful expression). Fulbeck states on his website that despite its utilization of common racial classifications, the Hapa project is fundamentally a project about identity rather than race, "it's about identity using race as a starting point." He argues that race in itself is not biologically determined, but socially created.

The appeal of this project lies mainly in its subversive attitude, and a refusal, on the part of participants and artist alike, to be confined by conventional geographic, racial or ethnic definitions. Fulbeck cleverly creates a definite level of chaos through brief texts presented in the hand-writing (and doodling) of the varying participants. Fulbeck's website contains a collection of the portrait series, displayed as an interlocking grid of images. The site's clean and simple design does not distract from the images themselves. Overall, it is powerful presentation that serves as a successful critique of racial stereotypes.

Under the Phoenix Tree. Julia Wang is a photographer, educator, and researcher based in New York City. As the daughter of immigrant parents from Taiwan, Wang spent a month in their home country, exploring the heritage she had shrugged off as a child in hopes of blending in 
better with her American surroundings. She takes the viewer in her quest for self-discovery. The project was named after delonix regis, also known in Chinese as the phoenix tree, "it blooms bright red flowers all over Taiwan at the start of the summer and end of the school year," Wang said on the landing page of her project. She also reveals that what she learned on her journey was not only the acceptance of two cultures but also the strength of her family and the preservation of their legacy. The pictures, published on her website, transcend how multiculturalism manifests itself in the perception and identity of those who were raised between two cultures. The website, however, lacks substantial details like dates and captions.

\section{Documentary Films}

Between Two Worlds. This documentary (2015) is a partnership between Think TV (Greater Dayton Public Television) and Wright State University's Asian and Native American Center in commemoration of the 40th anniversary of the end of the Vietnam War (1975-2015). The center's mission is to help students thrive by recruiting, retaining, and connecting with Latino, Asian, and Native American faculty and staff members. And while the documentary functions as a publicity piece for the center, it is also an example of a documentary project that can be produced on a limited budget. "Between Two Worlds" is a two-part documentary which features the remarkable stories of Vietnamese Americans and their families in the Dayton community. Even though this documentary tells the stories of Vietnamese Americans in Dayton, Ohio, their stories exemplify untold stories of other Vietnamese Americans in small or big cities around the nation.

Between Two Worlds: Dayton's Vietnamese American Community (part one) was premiered in April 2015. It tells the remarkable stories of Vietnamese Americans who made the painful decision to leave their homes in Vietnam, the dangers of their journey and the 
challenges of making a new life in a strange land. Between Two Worlds: The Next Generation (part two) introduces six second-generation Vietnamese Americans whose parents escaped Vietnam, eventually arriving in the Dayton area, with very little except their language and traditions. The overarching theme explored here revolves around what is lost and what is gained during the process of assimilation into a new culture.

Chinese Food: An All-American Cuisine. This four-part video series (AJ+, 2017) starts off by stating that there are now more than 4 million Chinese people living in the United States. Most of these immigrants came in the last few decades, starting in the ' 60 s as the liberalization of the American immigration policy in 1965 brought new arrivals from Hong Kong, Taiwan, and the Mainland, who in turn brought with them the foods they had enjoyed in areas like Hunan, Sichuan, Taipei, and Shanghai. As a result, many first-wave Chinese immigrants opened restaurants and catered Chinese food to American taste buds.

This series leaves you with a sense that Chinese immigrants had more than just an impact on the food scene in the U.S. The videos, produced by AJ+, explore themes that encompasses food, culture, the unique history of Chinese Americans, the economics behind Chinese food, and even politics.

\section{Am I: Too African to be American or Too American to be African?}

This film (2015) explores the tensions of being both African and American. The film deals a lot with the simultaneous rejection that the children of African immigrants face from both their parents' culture and what might be called "black American culture." The filmmaker Nadia Sasso, born in the United States to parents who immigrated from Sierra Leone, brings viewers behind the scenes in her subjects' lives and makes their culture-traversing experiences accessible for everyone. "I created the film as a way to not only explore how immigrants and their offspring 
engage with the issue of bicultural identity politics on the American and African landscapes, but to create a dialogue between the generations," Sasso revealed in a press release. "Cultural dualism is a reality that affects everyone, from our President of the United States, Barack Obama to everyday citizens like myself."

Sasso’s released “Am I: Too African To Be American Or Too American To Be African?” in 2015. The project draws on candid interviews with first-generation West AfricanAmericans_-including, notably, “Awkward Black Girl” creator Issa Rae. The film specifically looks at how these women wrestle with concepts of race, complexion, gender, and heritage among other issues. The women talk about relating to peers of different backgrounds, the disconnect between their parents' and American culture, and claiming their place in the American tapestry. "It's a fine line," says Sierra Leonean-American Mariama Jalloh-Heyward in the movie's first trailer. "You have to get your identity together. You've got to be able to be a chameleon sometimes, be in both places."

The film exemplifies a comprehensive examination of a unique perspective that is rarely picked up or depicted by other films in the media industry.

Syrians in America. After President Donald Trump halted the resettlement of Syrian refugees and banned Syrians from entering the U.S., AJ+ producer Omar Duwaji started researching the history of Syrian immigration to the U.S. to prove that Syrians have been here all along. As he explains in a feature article he wrote on Aljazeera website, Duwaji (2017) learned the following: Hudson Street was the center of "Syriantown" or "Little Syria" in Boston. Starting in the $1880 \mathrm{~s}$, it had become a neighborhood for Syrian immigrants in Boston. It was home to Syrian churches, grocery stores, civic associations and small businesses. The famous writer Khalil Gibran made his home in this neighborhood when he first immigrated to the U.S. 
Duwaji embarked on a journey to bring multigenerational stories of Syrian immigration to the U.S. Through this three-part video (AJ+, 2017), he identified a descendant of early Syrian immigrants, his Syrian parents who immigrated to the U.S. in 1981, and a family of Syrian refugees who have arrived after the Syrian conflict began in 2011. The series starts off by tracing the history of Syrians in the U.S. In the first video, Duwaji met Olivia Waishek at her home in West Roxbury, Boston. She has lived in the same house since 1963, when she was forced out of her original home in Boston's Syriantown. Her parents had lived in Syriantown since the early 1900s. In their day, it was a thriving neighborhood in the heart of Boston. Olivia described what it was like to grow up there and what had happened. In that video, one can discover the depth of the history of Arab-Americans in Boston.

In the second video of this series, Duwaji explored, by talking to his immigrant parents, what it meant for them as new immigrants to raise children in the U.S. and how important it was to pass along their language and culture to them. For the last part of this series, Duwaji helps the viewer get a glimpse into the life of Syrians refugees. Talking to his last interviewees, the Abdo family, Duwaji admired the bravery of this family of Syrian refugees opening up about the tragedy that had befallen them and how they are adjusting to their new home in America.

According to Duwaji, the series takeaway message rests on the meaning of home, "Home - that four-letter word is really why we produced this series; to talk about this place called the United States that I call home," Duwaji said on Aljazeera website. "I now understand that home isn't necessarily where you were born or where you are from. Home is the place where you are made to feel accepted by others in your community, where you are most comfortable with yourself and those around you." 
Although the series possess an obvious bias toward the subject (given the producer's nationality and the fact that he is featuring his parents), the film's level of access and comprehensive look at Syrians in the United States, including their history and current status, humanizes the issue of immigrants and refugees.

\section{Podcasts projects}

How America is melting in its pot-Otherhood. Otherhood is a Public Radio International (PRI) podcast created and hosted by Rupa Shenoy (2016) about the people who came to the United States as children or are the children of immigrants. As described in the podcast introduction, those individuals are shaped by the same experiences and motivated by many of the same emotions. Exploring stories of the second-generation American experience always have many layers to unfold. They face recurrent situations where they find themselves explaining their nationality and origin. Those moments lead to a series of conscious decisions that they make day in, day out, trying to minimize some of the awkwardness of these encounters, it also takes a toll on their identity that lies between two cultures.

These themes are brilliantly weaved into the interviews conducted with immigrants' children from different descent. In this podcast's episodes dubbed "How America is melting in its pot," they share their stories, talk about their upbringing and weigh in on navigating layers of culture, time, and geography.

\section{Narrative Theory}

As long as human beings have had the power of speech, they have been speaking in narratives, which is a form of representation, so goes the theory (O'Shaughnessy \& Stadler 2002: 127). Today, in a world dominated by print and electronic media, our sense of reality is increasingly structured by narrative. As such, narrative is historically positioned to turn 
information and events into structures that are meaningful to their audiences. Narrative is realized in many different media. Narratives in films, television radio, and in various media of popular print culture, otherwise known as 'mass media' use storytelling as a way of understanding and relating to the world around us. Media projects tell us stories about ourselves and the world we live in. Storytelling becomes a crucial means of communication and most of us do it all the time. In the introduction of his book "Somebody told me," Rick Bragg (2001) talks about the power and skill of storytelling and how storytellers can telegraph straight to our brains feelings we never felt. All storytellers have the gift of lending a voice to the voiceless.

Narrative theory is a concept in communication theory that was developed by Walter R. Fisher. The concept was adopted from the oldest form of communication, storytelling. Fisher (1987) stated that all meaningful communication is in the form of storytelling. Peoples past experiences influence our need for communication and also base our behavior. Thus, narrative theory is very helpful in analyzing the nature of human communication.

All forms of documentary projects, whether they are comprised of film, still images, audio, text, or a combination of those, tell stories, imbuing them strongly with narrative logic. Narrative logic, according to Fisher (1987) underlies all forms of human communication, and it is used by the human species to interpret and evaluate new stories against older stories.

The narrative paradigm, as described by Fisher (1987) sees people as storytellers, as authors and co-authors who creatively read and evaluate the texts of life. A narrative perspective focuses on existing institutions as providing plots that are always in the process of re-creation rather than existing as settled scripts. Narratives enable us to understand the actions of others, because we all live out narratives in our lives and because we understand our own lives in terms of narratives. In other words, telling stories and understanding them is a trait shared by all 
humans. According to Fisher, "the narrative paradigm proposes that human beings are inherently storytellers who have a natural capacity to recognize the coherence and fidelity of stories they tell and experience" (Fisher, 1987, p. 24). Fisher suggests that people experience and comprehend life as a series of ongoing narratives, as conflicts, characters, beginnings, middles, and ends. The various modes of communication - all forms of symbolic action - may be seen as stories. Fisher sees the narrative paradigm as encompassing all facets of storytelling. In the paradigm, people's role as storytellers includes being authors as well as being part of the story. In other words, people play many intertwined roles that are dependent on each other. Every person who is connected to a documentary is fulfilling his or her function in the narrative.

A goal of this project is to create a documentary using the narrative theory which will allow viewers to compare stories. If viewers can identify with the families that appear in the documentary, they will be able to compare the character's stories with stories from their own lives. This will allow viewers to share in the character's experiences, much in the way that Fisher believed that the characters in a documentary and the creators of documentaries share their stories. Fisher theorized that narrative, as a feature of human nature, crosses all barriers of time and culture to be shared by all. Intimacy between persons does not require knowing the details of each other's life; it glows in moments of true awareness and exchange.

There are many existing narratives surrounding children of immigrants, specifically, the second-generation. The narratives portrayed in this documentary will be used to examine the differing ways in which second-generation Americans feel about their heritage and upbringing between two worlds. Their narration will bring us closer to the delicate balance of their identities, one that they have to exercise, and the challenges of traversing semipermeable layers of culture. The individual narratives will also allow for an examination of different parenting 
styles that these families use to keep their children connected to their roots, and/or blended in the American society. Together, the stories will offer a glimpse into the lives of some of the people who come together to form this rich fabric in WV. As a whole, the stories will provide a narrative that proves that labels like are not more than starting-points, which if followed into actual experience for only a moment are quickly left behind. Those parents contain within themselves their roots as well as their children present and future. They are the perfect embodiment of living beyond borders and their stories are not static or uniform. Each story is unique. Each intimate exchange has a locale which partakes in the quality of the human encounter (Tuan, 2014, p. 141).

The themes that will be explored across all families include: identity, assimilation to the American culture, where the friction is felt, cultural preservation, and the definition of home. These themes were derived from the research I did as well as the conversations I had previously with some of those families. The next section encloses a brief about each one of them.

Assimilation to American culture. Salins Peter (1997) argued that America's vitality as a nation, depends on its being as successful in assimilating its newest immigrants as it was in integrating earlier immigrant groups. He showed how America's unique social compact of assimilation has permitted immigrants and their descendants to hold on to their ethnic traditions even as they acquired an American identity. However, some scholars contend that the assimilation process is inevitable and consists of gradually deserting old cultural and behavioral patterns in favor of new ones in order to gain equal access to opportunities within society (Caytas, 2012).

Through the stories presented in this project, these theories will be explored to see how they apply in the real world of second-generation Americans and their families. By drawing 
attention to the question "does assimilation mean giving up your heritage and roots?", this project seeks to systemize humanistic insights to lend a realistic perspective to those theories.

Cultural preservation. The contemporary population of major American urban centers and metropolitan cities like New York embraces its multicultural and ethnic inclusiveness more than it ever had during the last forty to sixty years. Under these circumstances, it might seem that assimilation and cultural preservation are perfectly compatible as they both help creating the cultural richness that characterizes life in a vibrant metropolis (Caytas, 2012). And yet, a closer reading of studies that surveyed successive generations of immigrants shows the reality of an ongoing conflict between their desire for cultural preservation and a tendency to conform to host country culture. All these personal and group identity struggles reveal inherent mutual exclusivity between assimilation and cultural preservation within immigrant groups. This begs an important question: if this is the case with metropolitan areas, then how does that translate in areas with less cultural diversity?

To some scholars, cultural preservation in conjunction with assimilation is not only possible but indeed advantageous to an individual able to draw strengths from two divergent cultures. As sociologist Min Zhou (1997) explains, "the pluralist perspective offers an alternative way of viewing the host society, treating members of ethnic minority groups as a part of the American population rather than as foreigners or outsiders and presenting ethnic or immigrant cultures as integral segments of American society." The ability to navigate two different ethnic backgrounds with integrity creates a unique cultural niche for a person enabled to serve as an intermediary between two worlds. An option to mix and match qualities drawn from both backgrounds to create the most successful combination of the two within the framework of the dominant culture seems to be a tangible advantage of all bicultural individuals. 
There are several ways immigrants and their families can maintain and preserve their culture. One of the most important ways is to continue to speak their language. By speaking their native tongue in their home, they maintain a sense of pride. A series of studies on immigrant children in the U.S. published by Min Zhou (1997) quotes sources like Maria Eugenia MatuteBianchi who claims that "fully bilingual young Mexican-Americans tended to perform better in school than those who lacked proficient bilingual skills."

However cultural preservation is more complex than that. The term itself begs some questions like: What culture we are talking about? What is to preserve? Are we talking about the culture of the home country with regard to immigrants? Does preservation in that case mean to freeze the culture over time and ignore the changes in the home country and all interactions within the new society, to reject all cultural experiences that can be added to life experiences?

Friction/Tension. Against the backdrop of the aforementioned context, it becomes clear that embracing two worlds and calibrating the balance between two distinct cultures can become both an asset and a challenge. On the one hand, second-generation Americans, born to at least one immigrant parent, have what Kasinitz, Mollenkopf, Waters, \& Holdaway (2008) call "the second-generation advantage." They benefit from being a part of two cultures by combining American and parental cultural beliefs and practices and creating new norms and beliefs about how to live in the world. On the other hand, with immigrants and their families, opportunities for more interaction can also lead to opportunities for more conflict. It all begins early on, when these children start noticing the differences in terms of their non-conventional American names, their facial features, food, holidays, and culture compared to their native-born peers.

In addition to the usual set of responsibilities that any parents assume, those parents often find themselves in a situation where they rely on their inequity and fortitude. They encourage 
these traits in their children to balance two different worlds and move fluidly between them (McCarthy, 1998).

Clearly, not every immigrant experience is created equal, and there may be no better way to convey that than through the complex, disparate relationships within multigenerational families. Their lives undergo recurrent phases of ease as well as tension. This project will attempt to inch closer towards the challenges as well as the perks from the perspective of those who experience them firsthand.

Home. Yi-Fu Tuan (2014) explains that home is what supports people's livelihood. The profound attachment to the homeland appears to be a worldwide phenomenon. It is not limited to any particular culture or economy. The city or land is viewed as mother, and it nourishes; it is an archive of fond memories. Attachment to homeland may come though simply with familiarity and ease, with the assurance of nurture and security, with the memory of sounds and smells, of communal activities and homely pleasures accumulated over time. It is difficult to articulate quiet attachment of this type (p.159).

Home is, of course, more than a complex and shifting viewpoint or feeling. The question that imposes itself here: does the meaning of home change when you leave your home country and move to another one? One can also wonder: what does it take for a man to live comfortably and call a place home? Is home necessarily where you were born or where you are from? Or is it the place where you feel accepted by others in your community, where you are most comfortable with yourself and those around you? No one can answer those questions better than those who lived through it all. This is where the project will turn to the parents to fathom this idea.

Identity. The first environment an infant explores is his or her parents. Although children come under cultural influences as soon as they are born, the biological imperatives of growth 
nonetheless impose rising curves of learning and understanding that are alike and hence may be said to transcend the specific emphases of culture. (Tuan, 2014, p.19). Children of immigrants often struggle to relate to their parents' identity because they lack the environmental elements that constitute their culture, such as nationality, language, clothing, and diet. This dichotomy affects second-generation immigrants of all ethnicities.

Culture strongly influences human behavior and values. It is the underlying foundation of traditions and beliefs that help a person relate to the world around them. As Yi-Fu Tuan (2014) clarifies, in large measure, culture dictates the focus and range of our awareness. Cultural identity involves several aspects of a person's being. Race, nationality, gender, location, age, gender, sexuality, history, and religious beliefs are put together to form a cultural identity. By combining each of these elements, a theory is created as to why a person acts and behaves the way they do.

A person's true identity includes their culture and heritage as two of the most integral pieces of the puzzle. Culture and identity go hand in hand. When a person identifies with their culture, they often embrace traditions that have been passed down through the years. The cultural identity links a person to their heritage can help them to identify with others who have the same traditions and basic belief systems. The definition of cultural identity, in its most basic form, is a sense of belonging.

Against this backdrop, second-generation Americans find themselves between not only one, but two cultures weighing on their self-identification. This identity is exemplified in Pew Research survey of Latinos and Asian Americans which have found that a majority of secondgeneration adults consider themselves to be "typical Americans" in addition to identifying themselves by their family’s country of origin (Pew Research Center, 2012). 


\section{Research Statement}

This project endeavors to pose an inquiry into broad issues of personal identity, cultural significance and the perception of home with the overarching theme of immigration. By focusing on stories of three second-generation Americans of different descent in West Virginia, this multimedia project includes content curated by the project author (photo, video, written stories, data visualizations, maps) and information selected by the participants themselves. The content will add to the information available on different cultural communities in West Virginia in general, and on the second generation in particular. It is hoped the project, through its portrayals of these individuals and their immigrant families, will help to dispel and counter some of the stereotypical depictions of immigrants. With this goal in mind, this project attempts to communicate a more complex and nuanced portrait of these individuals and present their stories in a way that differs from the typically immigrants' lives portrayed by the media. Viewers may find common grounds with these families, relate to their stories, and develop feelings of comfort and familiarity. They may even start formulating new perspectives, contradicting to the widely shared stereotypes about other cultures. Visual stories will allow viewers into the lives of each family, allowing for a better understanding of each narrative.

The project seeks to feed the American viewer's curiosity in exploring the world visually beyond the range of what he is acquainted with, and to show international families who took home of America that their stories are worth sharing and celebrating.

\section{Intended Audience}

Whether we work or study or even stay at home, our chances of interacting with people from various races, ethnic groups and cultures is far greater now than it has been ever before. Thus, cultural diversity has become very important in today's world. This is why this project's 
intended audience is a broad one, including West Virginians, international families, people living in the U.S. and around the world. For those who want to learn about other cultures, but do not know where to start, a likely place to start might be picking up a book and reading about the cultures that interest them, or doing research online from reputable sites. The most immediate, and perhaps best, way to learn, though, is through listening and exploring the experience of a person from a different culture (Frau-Meigs, 2007).

The project will also resonate with immigrant families who will be able to see threads of their experiences represented. Representation isn't just about seeing yourself in art or culture it's about feeling connected to and seen as part of a larger community. It's important for people to have this feeling of belonging. This is critical for people's well-being anywhere in the world. One of the risks of not being represented, of quieting some voices and keeping some groups invisible, is that "the other" can fill your absence, your silence, with his or her own interpretation. When you can't read people, hear their voices, see their faces, you fill in the blanks, write your own story about who they are, you give in to a single narrative. As Chimamanda Ngozi Adichie puts it in her TED talk (2009), "when we reject a single story, when we realize there is never a single story about any place, we gain a kind of paradise."

\section{The Project}

\section{Project Description}

This project is driven by second-generation Americans and their families. In my quest for diversity and for better coverage of the issue, I included three second-generation youths (age 7 to 12), each of whom was born in the United States to first-generation immigrant parents born in three different countries, from three different continents. The amount of time that each family has spent in the United States differs, so does the parenting style for each one of them especially 
when it comes to calibrating a balance between their native culture and the American culture.

Given the age group targeted, the project required IRB review. An IRB protocol was created and approved by the review board (IRB Protocol \#1710816387).

\section{Project Methodology}

The methods used for creating documentary stories included photography, videos, and interviews. The latter was used to create text stories that accompanied the photographs/videos. A website was constructed to house the project elements and showcase multimedia documents of their stories.

First, interviews with subjects (parent and child) were conducted and recorded. Subjects were asked core questions based on ideas of assimilation to the American society, cultural preservation, where do second-generation Americans who navigate two cultures feel the friction, how do these families define home, self-identification, as well as personal additional follow-up questions based on their particular circumstances. The questions (found in Appendix I) were constructed to address each one of these concepts. Second, a combination of photographs, video and text were used to tell their stories. Visual storytelling provided insight into their lives in a way that text alone cannot. Photographic and video documentaries provided an opportunity for viewers to emphasize with story subjects by allowing viewers to witness subjects' lives and make their own decisions about what they see. Interviews were conducted at the subjects' homes while photo series/videos took place in different places (school, home, parks, religious places, sports practices) as they represent various aspects of their lives.

\section{Final Project Format}

This project resulted in the creation of a collection of documentary stories and a written report. Both parts are critical to the narrative and together offer a more complete perspective of 
the issue. The written report, which is added to the website, is where I included my analysis, impressions, what I have learned through these intimate encounters with participating families, and what I wish I could have done differently, in an attempt to complement and offer a more complete perspective of the issue. The report also included statistical data converted into visually compelling data visualizations. This data offers a broad view about immigration history and immigrants background in West Virginia. The goal of the report is to complement the documentary pieces, by making statistical information available, without having to include it in the documentary.

Eventually, each child/family was represented by a combination of a visual component either a video piece or photo series and an in-depth story. The visual component of this project offers multiple insights into the lives of my subjects that text alone cannot, while the in-depth stories include the interviews materials that couldn't be documented by photographs or videos. These stories serve as a window these families choices, traditions, language, food, their take on navigating two worlds, and crossing barriers of culture. The written pieces follow AP-style.

In an attempt to represent each child in his own words, another piece was added. After being photographed, each child handwrote his response to the question: "Do you consider yourself as American or (native nationality of parents), and why?". This is another part that carries their voices. These citations resist any scientific or orderly manners of description, letting the personal, the singular leak in to create their own moments of boundless, un-bordered existence. The personal texts accompanying the photographs cannot be summed up in charts, percentages, titles or boxes.

All project elements are housed on a website (daliaelsaid.com). The website was created using a WordPress theme that was be tailored to fit the project. WordPress allows users to easily 
build and modify websites, which in combination with the many WordPress themes that are available, allows flexibility in creating the website. The publication of this project on a website is crucial, as it will allow anyone who has access to the internet to view the project. Sebastiao Salgado believed that there is no person in the world who should be protected from pictures. $\mathrm{He}$ believed that a documentary photographer was "a vector connecting the different realities of people around the world" (Light, 2000, p. 10). The ultimate goal of this project is to create a connection between the viewer and these families' stories. The viewer may be American, foreign resident living in the U.S., or living on the other side of the world, and a website will ensure that the project will have the greatest opportunity to make connections.

This project (once published) will be shared with the participants and their families. Ultimately, I hope to continue this work in the future adding to the work that will be featured on the website by creating other dimensions, with other children, potentially in other parts of the world, something that would grow into a visual archive of the world's children. Last but not least, I hope I can have this project published in other outlets and publications that may find the featured stories of significance to them like: 100 Days in Appalachia, Al Jazeera, NPR WVa, and others. Arab, Indian, Turkish, African heritage organizations may also be interested in having access to these stories, and distributing them to others.

\section{Professional and Educational Qualifications}

Throughout my studies, I have focused on ideas of diversity, representation, and inclusion. This project has allowed me to connect those ideas with my practical training as a journalist. During the two years of my master's program, I have always enjoyed multimedia storytelling. At WVU, I expanded my ability to share the stories of others by learning basic documentary and photojournalism skills. 
This project enabled me to bring all of these experiences together, adding to them data visualization techniques and website building. A multimedia project was useful to me professionally; it was also the best medium to share these stories.

Skill Development. Through this project, I have expanded my skill-set, learning more about video editing, photojournalism, website building, and data visualization.

I used infogram.com to learn new skills in creating data visualizations. This website helped me contextualize immigrants background in West Virginia to create visually appealing and easily understood graphics to complement my stories. This information was gathered from the Migration Policy Institute and the American Immigration Council. I also developed a proficiency in creating short video documentaries, from conception to script writing, video, and audio editing.

\section{Project Limitations}

This project has several limitations. Time constraints were one of them. Documentary projects require ample time to cover all aspects. This project started in fall semester 2017. While working on the project, I held a graduate assistantship and took an independent study class. I was also pregnant with my first child and my due date coincided with my defense date. That required adding extra hours ( 25 hours a week) from Spring semester to present, to make up for the time of absence during and after the baby delivery.

Another limitation to that project stems from the fact that it features three families. Each of whom represents one angle, one perspective. Thus, it is not by any means or stretch of imagination reflective of all immigrant families. Furthermore, all three children were males, so there is no equal representation of gender. The subject matter itself also created its own limitations. Because the project deals with children and their parents, a lot of planning and 
communicating had to be done which necessitated giving parents enough notice to schedule any of our meetings to accommodate their busy schedule.

Last but not least, because of the scope of the project, not all subjects who originally agreed to the project were able to participate to its completion. This resulted in several searches for appropriate subjects throughout the project period. It also prompted me to add another piece to the website addressing that specific challenge in a blog post.

\section{Timeline}

Explanation. An important element of this project has been becoming familiar, and building a rapport not only with the parents but also their children. The process of identifying second-generation Americans by reaching out to schools impacted the timeline. In order to do the project well, I also needed to focus on developing new skills in mediums that are useful for telling stories. Because of this, a multimedia approach was most prudent. However, my experience thus far has primarily been in short documentary stories and writing. For this project, I learned how to bring these elements together, also picking up how to develop my photography skills, as well as data visualization techniques and website building.

\section{Timeline: Full Work Schedule.}

2017 August/September: Reached out to North Elementary school to get their permission to distribute recruitment forms to children who fit the project criteria (born in the U.S. to foreignborn parents).

2017 September 15: Developed "Core Questions" and completed interviews preparation work. 2017 September 20: Collected basic background information on the history of immigrants in West Virginia, ideas of assimilation, cultural preservation, home and identity, and background research on other projects addressing the same issue. 
2017 September 30: identified two families, began reaching out to interview participants, and started developing working relationship with them.

2017 September/December: Collected content from the two families.

2017 October/November: Finished project proposal. Sent to Committee Chair. Incorporated suggestions and edits.

2018 January: Received feedback on proposal from Committee Chair and other Committee Members. Prepared for Project Proposal Defense.

2018 February 19: Defended proposal.

2018 April: Completed all content collection.

2018 January to April: Went through content, worked on creating a website housing all project elements.

2018 April 25: Defend project. 


\section{Professional Report}

It's not uncommon to hear people say that stories make the world a better place. The past two years I spent pursuing my master's degree in Journalism made me learn that when people tell their stories to each other and are heard, magic happens. People bond. Barriers dissolve. Connections are made. Trust increases. Knowledge is transmitted. Wisdom is shared. A common language is birthed. That's why, our ancestors stood around the fire and shared their stories with each other. Survival depended on it and so did the emotional well-being of the tribe.

Over the past eight months, I have been trying to shine a light on the stories of those who are rarely heard or inadequately represented in the media. The heroes of this project are three children and their immigrant families. Since its inception, this nation has been continually infused with the energy of newcomers who came from all over the world hoping for a better future. This latter word is key to why these families made the choice of moving to another country.

Throughout the years, these waves of immigrants created a rich, colorful mosaic in the American society with their religion, music, fashion, food, and other cultural contributions. However, at this point of history, immigration has become a hot-button topic in the United States, one that not only affects national policy, but also Americans' perception of other nationalities, races, and ethnicities living here. The U.S. 2016 election season, with Donald Trump's discussion of walls and bans, further brought immigration issues into public consciousness. According to the 2016 Current Population Survey (CPS), immigrants and their U.S.-born children now number approximately 84.3 million people, or 27 percent of the overall U.S. population. Certainly, these numbers and statistics are important tools, but there is another important ingredient in that stew: Experience. There is no room for that on official census forms, 
polls, or debates. They need to be complemented by real life stories and experiences of those defined and measured in these figures. Statistics do not tell the story of immigration. People do.

And since there are many chapters that can be told when talking about a family's experience leaving one country for another, I thought about approaching their experience from the point of view of raising children while traversing semipermeable layers of culture, time, and geography. In much of the debate over immigration, there is little attention devoted to U.S.-born children of immigrants, commonly referred to as second-generation immigrants. Those individuals are more than numbers, more than the reports that analyze their educational attainment and economic standing. This is why I embarked on this journey in an attempt to put a face to second-generation Americans.

The idea of this project was first developed in a class taught by my professor and mentor "Lois Raimondo." It was shaped by conversations I've had with second-generation Americans, age 7 to 15 , and their mothers. The families talked about the daily details that compound their lives. The children reflected on self-identification, a concept that gains another dimension when you navigate two cultures at once. The mothers addressed the challenges as well as the perks of raising their children in a cultural upbringing different than the one they had.

One story in particular stuck with me. A South Korean mother told me that her five-yearold daughter was once asked to dress up as a princess for one of her school activities. The little girl found a hard time accomplishing the seemingly fun task. "Princesses have wide eyes, they are tall and slim, with long, flowing, and mostly golden hair," she said to her mum. To the little girl, this was the benchmark of beauty and when she didn't "see" herself, she felt out of place. This is why representation, not only diversity, matters. 
Every time you see yourself in a magazine, billboard, film, book, cartoon, or even a toy, it's a message that you matter, you are part of the national story, that you're valued. And this begs an important question: Where exactly are we telling these children that they are heroes in our stories?

Representation is not an added layer; it is absolutely fundamental and it is what people expect from culture and politics. And since I am in no position to affect politics, I thought I would use the skills that I learned from my professors and mentors to lend a voice and represent immigrant families and their children.

The rationale for conducting this project with children rather than adults stems from the fact that children's thoughts are raw, honest, unfiltered, and spontaneous. They are caught up in the excitement of people, places, and events. They are more open to the world and relate to their surroundings with a directness and intimacy that are the envy of adults bruised by life. I also narrowed the location to one small portion of the U.S.: Morgantown city in the state of West Virginia, and there is a significance to that. This Appalachian region has long been considered a predominantly white section of the United States, particularly in comparison with the rest of the country. In fact, a map created by Randy Olson in 2014 depicting how racial diversity is spread across the United States, found Tucker county in West Virginia to be the least diverse county in the U.S. with 100 percent white population. However, this broad generalization fails to take into account the immense diversity and subcultures of some of the most seemingly homogenous places, particularly those in rural America. To varying degrees, diversity does exist in West Virginia - whether socioeconomic, religious, cultural, racial, or in national heritage. West Virginia is home to a rich diversity of cultures and communities representing people from all around the world who have found their way to this Appalachian state. The presence of these 
communities and their willingness to share their traditions is a valuable asset to cultural life and a testament to the fact that there is not one story or voice of West Virginia.

To explore the similarities and differences with a topic that has commonality, I was interested in specific concepts that gain another dimension with immigrant families. These concepts were derived from the research I did as well as the conversations I previously had with some of these families. They were based on the ideas of identity, assimilation to the American culture, where the friction is felt, cultural preservation, and the definition of home.

Raising children comes with new sets of responsibilities. Adding two, sometimes three cultures to the mix makes the task at hand even harder.

My three heroes were born to Sierra Leonean and Guinean, Turkish, and Indian parents. It took few months, several visits, countless talks, and numerous occasions to put their pieces together. It equally took an undivided attention to their tones, appearances, and personal spaces to reveal the next subtle details.

The parents I met welcomed their newborns to the world with a name that carries their native culture, one that their descendants will, in return, carry for life. They all reflected on giving their children a name with a symbolic relevance.

Daghan, whose name translates to "king of the mountains," was given that name by his Turkish parents to amalgamate two countries and cultures. The name symbolizes the city of Morgantown, known as the Mountain state; it also ties him to his Turkish roots. Siddanth's Hindu name was similarly chosen by his Indian parents to remind him of his heritage and to express their gratitude for having a child after many years of trying. Given their fascination with history, their African descent, and their Muslim faith, Malik's parents wanted to give him a name that has a meaning. Thus, came the name Malik, "the king of kings." 
Couple of years down the road, as their children learned to talk, every couple had a different approach navigating the primary mean of communication: language. Language itself reveals the intimate connectivity among people, space, and time. It's a binding feature of shared identity, even for those that have never set foot in the land from which it originated. Every family had its own language, even if that language was composed of two distinctly different languages. What these families opened my eyes to is that raising bilingual children does not always come with ease. Not only does it take a lot of intentional planning from the parents; other factors are at play. Sometimes the child has no interest in learning his parents' native language. Sometimes parents come from countries that display an astonishing array of languages. This is an area where all shades of grey tend to show.

Across all families, food was a constant reminder of the homeland. A clear consensus was shared among children and parents on that front. And as simple as it might sound, the food, smells and sounds seemed to transport the parents' roots. To them, food was another way to teach and show their children the India, Turkey, Sierra Leone and Guinea they knew. And when life in America seemed particularly alien, the one thing that always helped these families was food from home. They found solace in their warm kitchens, cooking up a filling pot of curry, Dolma, or Cassava leaf soup.

As we delved deeper beyond the tangible connections to one's homeland, the parents raised an important point. Raising children between two cultures undergoes recurrent phases of tension and ease. With a prevailing sentiment that this multicultural experience is something to be enjoyed, not something to be endured, they were quick to point out that some days run smoothly, other days are met with confusion that can sometimes turn into cultural faux pas. The 
parents I met shared a desire to raise their children to be strong and kind with a respect for both cultures. However, with each culture having its own symbols of intimacy, traditions, practices, and its own standards of what is or isn't socially acceptable, straddling two cultures can become a juggling act.

With immigrants and their children, opportunities for more interaction can also lead to opportunities for more conflict. In their documentary pieces and stories, each parent recalled a moment where his child started noticing, early on, the differences in terms of his nonconventional American name, his facial features, food, holidays, and culture compared to his native-born peers. All parents agreed that it takes time, patience, and leading by example to walk your child through these puzzling incidents using them as teachable moments rather than a collision of cultures. The answers may not always appeal to the child's curiosity and they may invite more questions on his end. It is a constant learning process.

Talking to the parents, I was able to see that they were all proud of their roots. They made sure to give their children some of that cultural grounding that sustains them while embracing the American identity that they all valued. And by talking to the children, I was able to see how each one of them has carved his own place on the spectrum of identity. Albeit their young age, Siddanth, Daghan and Malik had a clear idea of the multiple layers of their identities, most importantly, they were given the freedom to say which one took precedence. I was impressed by their sure-footed confidence answering the question, "do you consider yourself as American or Indian, Turkish, Sierra Leonean/Guinean?" and equally impressed by the rationale they gave. In an attempt to preserve these moments, I asked each one of them to document, in his own handwriting, his answer. I wanted these personal citations along with their portraits to carry their own voices in a way that cannot be summed up in charts, percentages, titles, or boxes. 
Throughout our meetings, the insights that both parents and children offered have opened eyes. The parents intimate accounts encapsulated their experiences as well as specific traits that revealed themselves effortlessly during our encounters. Janani’s peacefulness, calm demeanor, and maternal tone answering Siddanth's questions captivated me every time we met. Even when Siddanth's patience seemed to wear thin, she never tried to deflect or offer canned answers. She simply addressed each one of his questions with openness and grace. Their home felt like an enchanting oasis of tranquility. I was always welcomed like family, even sent home with Indian snacks and sweets. Janani showed me that migrating to the United States didn't mean pushing everything aside but rather taking it all in. To this family, the hybridity of two cultures is seen as a blessing. The two complement each other.

Coming from the African continent myself, I knew that there is no continent more blessed with striking beauty, history, and diversity than the African Motherland. I saw these features wrapped up in Tamba's words and articulated in his answers and thoughts. This family has been refining a delicate balance between embracing the identity of one's place of birth and residence. They showed me that the presence of one culture doesn't signal the extinction of the other, that the present doesn't negate the past, they can both coexist and reconcile. Albeit their upbringing in entirely different worlds, Tamba was the star of straddling both cultures. Being proud of his heritage certainly did a lot to impart cultural appreciation to his son. Even when he never stepped a foot in his father's homeland, Malik was bound to his African roots, loyal in heart if not on paper. Throughout our lengthy conversations, I was particularly impressed by Tamba's forward thinking views on parenting, culture, freedom, and global citizenship. His ideas spoke volume to his open mindset credited with helping him cope with any situation. He didn't 
need to question where he stands on the spectrum of identity or the definition of home as long as he seeks, keeps, and passes along the best of both worlds. He had a remarkable wisdom and an aptitude for always seeing the glass half full.

As an immigrant, working, single mother, Nihan wears many hats. Her story unfolds layers of cultural preservation, cultural tension, and assimilation. To her, drawing strengths from two divergent cultures is necessary, however, balancing aspects of both cultures doesn't come with ease. On the one hand, Nihan made a choice, eight years ago, to be humbled in a land and often in a language that are wholly foreign. She loved the possibilities of empowerment that this country represents, and what that meant for the future of her son. On the other hand, she fears that Daghan will grow distant to her and her culture. Her experience raising a child between two countries and cultures can thus be summed up in a relentless effort in creativity and a mind-altering amount of patience. Talking to Nihan felt like talking to an old friend I have known for years. With her warm smile and open heart, she was my window to Turkey. She talked about her culture with the utmost fondness and respect. More than anything, she treasured her culture's unmatched sense of family, close relationships, and hospitality. And to this hospitality, I can testify. Nihan never ceased a moment to make me feel welcomed. She shared parenting tips, cooking recipes, and even invited me over a typical Turkish breakfast. For Turks, breakfast or "kahvalti" happens every single day of the week, and it's just as much a ritual on Wednesday as it is on Sunday. And to replicate the Turkish authentic experience, breakfast was complemented by hot black tea served in tulip glasses, a sight that reminded me of my part of the world. 
With a rich array of feelings between shelter and venture, attachment and freedom, exploring the emotional repertoire was an equally important component to make these stories real and relatable. To some degree, the parents shared their struggle with homesickness when they first moved to the U.S. However, today, they are all averse to leaving the country they now call "home." Their answers on how to define home included a variation of the same meaning. It was the place where they felt safe, welcomed, and comfortable in their own skin.

By making these families more visible, I wanted this project to communicate a more complex and nuanced portrait of these individuals and present their stories in a way that differs from the typically immigrants' lives portrayed by the media.

Over the course of eight months, I was besotted with their tales. My conversations with the parents would drift into gossip about things we experience in common. They shared tips, lessons, and imparted their wisdom. As an international student and a first-time expectant mother living between two worlds myself, their words and stories offered a more realistic blueprint of how to raise children between two cultures. Their kindness and generosity warmed the frosty weather of Morgantown. I felt close to different corners of the world, in a remote corner away from my home country.

I fell in love with all three children and envied their unfiltered thoughts. I found myself sharing the same excitement they had for their creative projects, toys, and video games. The sweetness of that memory is something I will savor for years.

I learned about other cultures. More than anything, I learned that people from different cultures may differ in certain aspects, nonetheless, certain cross-cultural similarities exist, and they rest ultimately on the fact that man is the measure of all things. I saw the common ground that brings us all human beings together. Those parents contained within themselves their roots 
as well as their children's present and future. To me, they were the perfect embodiment of living beyond borders. Their narration suggested that the common metaphor referring to the U.S. as a "melting pot" may have now changed to a "mixed salad" where each cultural group contributes to the taste of the overall dish, while retaining its own unique flavor. It's a subtle distinction, but important.

Reflecting on the time I spent working on that project, I wish I had the chance to spend more time with each one of them to consume the rich details of their daily lives. I also hope I get to meet these young souls with big hearts few years down the road. It would be interesting to see how their thoughts will progress throughout the different phases of adolescence and adulthood where separating yourself from your parents is common. Will they distance themselves from their parents' cultures? Will the political climate overshadow their thoughts? Will their ideas differ? Will their place on the identity spectrum shift?

I also hope to continue this work in the future by creating other dimensions, with other children, potentially in other parts of the world, something that would grow into a visual archive of the world's children. 


\section{Bibliography}

Abel, J., \& Glass, I. (2002). Radio: An Illustrated Guide. Chicago, Ill.: WBEZ

Aj+ (Producer). (2017). Chinese Food: An All-American Cuisine. Retrieved from https://www.youtube.com/playlist?list=PLZd3QRtSy5LM4OwSoP6_HMM87jisKOzoT

Aj+ (Producer). (2017). Syrians In America. Retrieved from https://www.youtube.com/playlist?list=PLZd3QRtSy5LPRvn-HMojxxuLu6nh9D7CE

Association of American Medical Colleges. (2017). 2017 State Physician Workforce Data Book. Retrieved from https://www.aamc.org/download/447244/data/westvirginiaprofile.pdf Blinder, S. (2015a). Imagined Immigration: The Impact of Different Meanings of 'Immigrants' in Public Opinion and Policy Debates in Britain. Political Studies, 63(1):80-100.

Blinder, S. (2015b). Uk public opinion toward immigration: Overall attitudes and level of concern. Technical report, The Migration Observatory.

Borjas, G. J. (1999). Heavens Door: Immigration Policy and the American Economy. Princeton University Press.

Bragg, R. (2001). Somebody told me: the newspaper stories of Rick Bragg. New York: Vintage Books.

Bush, J., McLarty III, T. F., and Alden, E. H. 2009. U.S. immigration policy, Council on Foreign Relations: New York.

Caytas, J., (2012). Conundrum of an Immigrant: Assimilation versus Cultural Preservation (2012). Journal of Identity and Migration Studies Vol. 6, No. 2, pp. 36-54, Autumn/Winter 2012. 
Children in U.S. Immigrant Families. (2016, October 18). Retrieved October 06, 2017, from http://www.migrationpolicy.org/programs/data-hub/charts/children-immigrantfamilies?width $=1000 \&$ height $=850 \&$ iframe $=$ true

Citrin, J. and Sides, J. (2008). Immigration and the Imagined Community in Europe and the United States. Political Studies, 56(1):33-56.

Connor, P. (2016). International migration: Key findings from the U.S., Europe and the world. Retrieved from http://www.pewresearch.org/fact-tank/2016/12/15/internationalmigration-key-findings-from-the-u-s-europe-and-the-world/

Data USA. (n.d.). Data USA: Morgantown City. Retrieved from https://datausa.io/profile/geo/morgantown-wv/\#demographics

Fisher, W. R. (1987). Human communication as narration: toward a philosophy of reason, value, and action. Columbia, S.C.: University of South Carolina Press.

Frau-Meigs, D. (2007). PART I: Researching media internationalization: Cultural diversity and global media studies. Global Media \& Communication, 3(3), 260-266.

Fulbeck, K. (Photographer). The Hapa project. Retrieved from http://www.thehapaproject.com/ Funderburg, L. (2013, October). Changing faces. National Geographic. Retrieved from http://ngm.nationalgeographic.com/2013/10/changing-faces/funderburgtext?_ga $=2.236215041 .1052503637 .1517061470-1267836472.1516758456$

Gallup (2016). Immigration: http://www.gallup.com/poll/1660/immigration.aspx.

Gibson, C., \& Jung, K. (2005). Historical census statistics on population totals by race, 1790 to 1990, and by Hispanic origin, 1970 to 1990, for large cities and other urban places in the United States. Population Division Working Paper No. 76. U.S. Census Bureau. 
Graf, N. (2018). Americans see both good and bad in trends that are changing the workplace. Retrieved from http://www.pewresearch.org/fact-tank/2018/01/23/americans-see-bothgood-and-bad-in-trends-that-are-changing-the-workplace/

Greenberg B., Mastro D., Brand J. Minorities and the mass media: television into the 21st century. In: Bryant J, Zillmann D, eds. Media Effects: Advances in Theory and Research. 2nd ed. Mahwah, NJ: Lawrence Erlbaum Associate. 2002.

Heberle, V., \& Morgado, M. (2016). Discussing the representation of immigrants: An integrated view from SFL, CDA and Multimodality. International Journal of Language Studies, 10(2), 57-78.

IpsosMori (2014). Perceptions and Reality: Public Attitudes Towards Immigration. Report.

Jaafari, S., \& Kulkarni, S. (Producer). (2014, September 26). This young photographer brings the stories of immigrant children to light. Retrieved from https://www.pri.org/stories/201409-26/young-photographer-brings-stories-immigrant-children-light

Kasinitz, P., Mollenkopf, J., Waters, M., \& Holdaway, J. (2008). Inheriting the City: The Children of Immigrants Come of Age. Russell Sage Foundation. Retrieved from http://www.jstor.org/stable/10.7758/9781610446556

Krogstad, J. (2015). What Americans, Europeans think of immigrants. Retrieved from http://www.pewresearch.org/fact-tank/2015/09/24/what-americans-europeans-think-ofimmigrants/

Legal Immigration to the United States, 1820-Present. (2017, February 01). Retrieved October 06, 2017, from http://www.migrationpolicy.org/programs/data-hub/charts/AnnualNumber-of-US-Legal-Permanent-Residents? width=850\&height=850\&iframe=true 
Light, K. (2000). Witness in our time: working lives of documentary photographers.

Washington,

D.C.: Smithsonian Institution Press.

Maccarone, E. M. (2010). Ethical responsibilities to subjects and documentary filmmaking. Journal of Mass Media Ethics, 25(3), 192-206.

Marie, N. (2013, December 08). Am I: Too African to be American or Too American to be African? Retrieved October 06, 2017, from https://www.youtube.com/watch?v=Et3crszAXFc

Mark, M. E. (1990). The Photo Essay. Washington: Smithsonian Institution Press.

Maucci, Q. (Photographer). (2012). Portraits of A Generation: Children of Immigrants. Retrieved from http://www.quetzalmaucci.com/children-of-immigrants\#0

McCarthy K. (1998). Adaptation of immigrant children to the United States: A review of the literature (Working Paper No. 995). Princeton, NJ: Center for Research on Child Wellbeing. Retrieved from http://crcw.princeton.edu/workingpapers/WP98-03McCarthy.pdf

Migration Policy Institute. (2017). West Virginia: Demographics \& Social. Retrieved from https://www.migrationpolicy.org/data/state-profiles/state/demographics/WV

Narula, S. (2014, April 29). The 5 U.S. Counties Where Racial Diversity Is Highest_-and Lowest. The Atlantic. Retrieved from https://www.theatlantic.com/national/archive/2014/04/mapping-racial-diversity-bycounty/361388/

Norris, M. (2013, September 19). Visualizing Race, Identity, and Change. Retrieved October 06, 2017, from http://proof.nationalgeographic.com/2013/09/17/visualizing-change/ 
O’Shaughnessy, Michael, and Jane Stadler, Media and Society: An Introduction, 2nd edn, Melbourne: Oxford University Press, 2002.

Pollard, Kelvin M. 2004. A "New Diversity": Race and Ethnicity in the Appalachian Region. Washington, DC: Appalachian Regional Commission and Population Reference Bureau.Portes, A., \& Rumbaut, R. G. (n.d.). Legacies: the story of the immigrant secondgeneration. Berkeley, Calif.: University of California Press.

Portes, Alejandro, and Ruben Rumbaut. 2001. Legacies: The Story of the Immigrant Secondgeneration. Berkeley, CA: University of California Press.

"Power of POP: Media Analysis of Representations of Immigrants in Popular TV Shows." The Opportunity Agenda, May 2017, opportunityagenda.org/explore/resourcespublications/power-pop.

Salins, P. D. (1997). Assimilation, American style. New York: Basic Books.

Second-Generation Americans A Portrait of the Adult Children of Immigrants. (2013, February 7). Retrieved from http://www.pewsocialtrends.org/files/2013/02/FINAL_immigrant_generations_report_27-13.pdf

Sasso, N. (Director). (2015). Am I: Too African to be American or Too American to be African? Retrieved from http://www.amithefilm.com/

Saxena, J. (2017). Netflix Talks Diversity and Representation With \#FirstTimeISawMe. Retrieved from http://www.elle.com/culture/movies-tv/news/a47153/the-first-time-i-sawme-netflix-project/ 
Schoeller, M. (Photographer). (2013). Visualizing Race, Identity, and Change. Retrieved from http://ngm.nationalgeographic.com/2013/10/changing-faces/funderburgtext?_ga=2.199686573.287082159.1516758456-1267836472.1516758456

Shenoy, R. (Presenter). \& PRI (Producer). (2016, August 4). How America is melting in its pot. Retrieved from https://www.pri.org/programs/otherhood/how-america-melting-its-pot

Sniderman, P. M., Hagendoorn, L., and Prior, M. (2004). Predisposing Factors and Situational Triggers: Exclusionary Reactions to Immigrant Minorities. American Political Science Review, 98(01):35-49.

State Demographics Data - US. (2017, September 01). Retrieved October 06, 2017, from http://www.migrationpolicy.org/data/state-profiles/state/demographics/US

TED. (Producer). (2009). The danger of a single story. Retrieved from https://www.ted.com/talks/chimamanda_adichie_the_danger_of_a_single_story/transcript ?language $=$ en

Think TV (Producer). (2015). Between Two Worlds. Retrieved from http://www.thinktv.org/air/featured-programs/between-two-worlds-next-generation/

Tuan, Y. (2014). Space and place: the perspective of experience. Minnesota: University of Minnesota.

Tukachinsky, R., Mastro, D., Yarchi, M. (2015). Documenting portrayals of race/ethnicity on primetime television over a 20 -year span and their association with national-level racial/ethnic attitudes. Journal of Social Issues, 71, 17-38.

Wang, J. (Photographer). Under the Phoenix Tree. Retrieved from https://www.juliawang.com/under-the-phoenix-tree/ 
White, A. (2017). What the \#FirstTimeISawMe hashtag reveals about representation in media. Retrieved from https://www.vox.com/culture/2017/8/2/16075344/firsttimeisawmehashtag-netflix-media-representation

Wike, R. (2017). 5 charts showing where France's National Front draws its support. Retrived from http://www.pewresearch.org/fact-tank/2017/04/21/5-charts-showing-where-francesnational-front-draws-its-support/

Zhou, M. (1997). Growing Up American: The Challenge Confronting Immigrant Children and Children of Immigrants. Annual Review of Sociology, 23(1), 63-95. doi:10.1146/annurev.soc.23.1.63

Zong, J \& Batalova, J. (2017, March 8). Frequently Requested Statistics on Immigrants and Immigration in the United States. Retrieved from http://www.migrationpolicy.org/article/frequently-requested-statistics-immigrants-andimmigration-united-states

Zong, J \& Batalova, J. (2016, August 10). Naturalization Trends in the United States. Retrieved from https://www.migrationpolicy.org/article/naturalization-trends-united-states

\section{Questions to the children}

\section{Appendix I: Interview Core Questions}

1. What's your name? What does it mean? How do you pronounce it?

2. When you close your eyes, what is the first thing that you see when you think of Turkey, India, Syria, Mexico, Sierra Leone?

3. Are you more comfortable talking in English or Turkish, Indian, Arabic, Spanish?

4. What do you usually have for dinner? What is your comfort food?

5. What do you love most about your parents? 
6. Do you consider yourself Indian, Turkish, Syrian, Mexican, Sierra Leonean or American?

7. If you had to choose one favorite thing from each culture, what would it be?

8. What is your favorite holiday?

9. Can you think of something that you do when you visit Turkey, India, Syria, Mexico, Sierra Leone that is completely different from what you do in America (for example, how do you greet people, show respect for elderly, etc.?), does it confuse you?

10. What would you like to be when you grow up?

\section{Questions to the parent (mother/father)}

1. Can you walk me through your journey here in the U.S., when did you come, where did you first live, and when did you move to Morgantown?

2. What went through your mind when you were pregnant with your child knowing that he will be raised between two cultures?

3. What are the way through which you make your child connected to his roots?

4. What are the holidays that you celebrate here? What do they mean to you? How do you usually celebrate them here?

5. When you first came here, did you develop some coping techniques that helped live away from home?

6. What do you usually make for dinner?

7. What is your favorite thing from each culture?

8. Can you recall a moment where your kid came to you and was confused about something due to cultural difference? How did you handle that situation?

9. Was there a moment where you felt as an outsider in the U.S.?

10. Do you have any fears about raising your kid in the U.S? 
11. What are the perks/advantages of raising children in the U.S.?

12. Do you consider the U.S. or Turkey, India, Sierra Leone, Mexico, Syria to be your home? Why? How do you define home?

Consent Form (parents)

Principal Investigator

Department

Protocol Number

\section{Appendix II: Consent/ Assent Forms}

Co-Investigator(s)

Lois Raimondo

Reed College of Media

1710816387

\section{Introduction}

You, , and your child, , have been asked to participate in this media project. This project is being conducted by Dalia Elsaid to fulfill the requirements for a master dissertation in Reed College of Media under the supervision of Prof. Lois Raimondo, assistant professor, Shott Chair of Journalism in Reed College of Media at West Virginia University.

Purpose(s) of the Project

This media project aims to celebrate and showcase the value of diversity and inclusivity in our community by focusing on stories of second-generation Americans and their immigrant parents. Without learning about other cultures, we have no hope in understanding what the world around us is really like.

By talking, and more importantly, listening to your experience as an immigrant parent and your child's experience growing up between two cultures, we can learn about your culture, achieve a more coherent understanding of children of immigrants who were born in a country different than their parents', and get a step closer to connect and coexist.

Another goal of this project is to represent immigrant families like yours in their own words. Representation isn't just about seeing yourself in art or culture — it's about feeling connected to and seen as part of a larger community. It is critical for people to have this feeling of belonging anywhere in the world.

We expect to enroll approximately 4 families; a total of approximately 8 subjects ( 4 children and 4 parents) at all sites are expected to participate in this project.

We intend to interview you and your child then document your answers either by photographs or video. This documentary will capture you and your child's words, choices and likeness.

Description of Procedures

North Elementary School in Morgantown, West Virginia, known for being the largest and most ethnically diverse school in Morgantown, was contacted to help me reach the subjects, the second-generation American children (born in the U.S. to foreign-born parents). 
A form was distributed to your child since he/she falls under these criteria, to be handed to you. The form detailed the following:

a) The project description and purpose.

b) My supervisor's contact as well as mine.

c) A section for you to fill out indicating your country of origin, your child's name, and age.

d) A checkbox to mark whether you would like to be contacted to participate in this project, your contact details (phone/email) to get in touch with you in case of approval, and your signature.

Forms were collected from school. You declared your desire to be contacted to discuss your family's potential participation in the project. After contacting you, you set a time for us to meet at the location of your choosing to thoroughly go over the project details, purpose and timeline. During this meeting and after you agree to participate in this project, you will decide when and where our next meeting(s) will take place to conduct the recorded interviews with you and your child, as well as the video or photo series with the both of you.

I will ask you to read and sign a consent letter. You will keep a copy of that letter.

Interviews

Interview questions to you and your child will be sent to you beforehand.

The recorded interviews will take approximately 20-30 minutes.

Neither you nor your child have to answer any question that makes you uncomfortable.

You will be present when your child is being asked the questions.

Voluntary Participation

Your participation is completely voluntary. You can stop participating in this project whenever you want without any effect or penalty on you or your child.

Project timeline and Location(s)

The project will be performed at your home and any place you deem appropriate; it will take approximately one to two months for you and your child to complete depending on your availability and schedule.

In this project, your story (parent/child) will be represented in three different ways:

A. A visual narrative (either photo series or a video).

B. A word document (written story) including interview materials to provide an in-depth understanding of your story/experience.

C. You will be asked to write, in your own words, your hopes for your child on a portrait of $\mathrm{him} / \mathrm{her}$.

A website will be created for the sole purpose of displaying all the previous collection of documentary stories, videos and photographs. None of your contact details (address, phone number, email) will be shared or posted anywhere on the website.

Risks and Discomforts

There are no known or expected risks to your child from participating in this project. 
Benefits

Your child may not receive any direct benefit from this project. The knowledge gained from this project may eventually benefit others.

Financial Considerations

No payments will be made for participating in the project.

Confidentiality

This is a media graduation project for Reed Media College. One of professional project requirements is the publication/dissemination requirement: the professional project must result in a tangible media product delivered to an intended audience. Elaborating on that, a website will be created for the sole purpose of displaying all the previous collection of documentary stories, videos, professional report, and will be an integral part of the project.

All your contact details (address, phone number, email) will be kept confidential and will not be shared or posted anywhere.

Contact Persons

If you have any questions, concerns, or complaints about this project, you can contact Lois Raimondo at (304)-293-8708 or at lois.Raimondo@mail.wvu.edu.

For information regarding your child's rights, to discuss problems, concerns, to obtain information or offer input about the project, contact the Office of Integrity and Compliance (304) 293-7073.

Signatures

Upon signing this consent, you will receive a copy.

I consent that my child and I participate in this media project.

Signature of Parent or Guardian

$\begin{array}{lll}\text { Printed Name } & \text { Date } & \text { Time }\end{array}$

Signature of Investigator or Co-Investigator

Printed Name $\quad$ Date Time

\section{Assent Form (Children)}

Principal Investigator

Department

Protocol Number

Study Title Growing up between two worlds: A portrait of second generation Americans Co-Investigator(s)
Lois Raimondo

Reed College of Media

1710816387

Dalia Elsaid 
Introduction

You, , have been asked to participate in this media project, which has

been explained to you by Dalia Elsaid.

Purpose(s) of the Project

This project aims to celebrate diversity and show how enriching it is to have different cultures in one place.

By talking to you and your parents and sharing your story, you will help us learn more about your parents' culture and your experience as a second-generation American growing up between two cultures.

Description of Procedures

Project details, purpose and timeline will be explained to you and your parents.

If you agree to participate, you will be asked to sign this form.

Your parents will also be asked to sign another form called "consent letter". You will keep a copy of all the forms you signed.

Interviews

You and your parent will be asked some questions and your answers will be recorded to capture your own words.

This will take no more than 30 minutes.

You don't have to answer any question that makes you feel uncomfortable.

You may stop participating at any time and nothing bad will happen to you.

Your mother will be present when I ask you the questions.

We will then meet few more times to take pictures or video of you and your parents, this will help us tell your story.

We will meet at the time and place that you and your parents decide.

The project will take approximately one to two months, depending on your schedule, to complete the photo series or video.

Final Outcome

Your story will be presented in that project in three different ways:

A. Series of photos or a video.

B. A word document (story) that includes your interview answers.

C. Your parent will write, in his own words, his hopes and dreams for you on a portrait of yourself.

A website will be created and your story will be displayed.

Discomforts

There are no known or expected risks or discomforts from participating in this project.

Benefits

This project may not help you, but what we learn from it may help other people. 
Confidentiality

We promise that your address and contact information in this project will be kept a secret.

Voluntary Participation

You do not have to do this. No one will be mad at you if you refuse to do this or if you decide to quit. You can ask any question about the project, and all your questions will be answered.

Contact Persons

If you have any questions or complaints about this project, you can contact Lois Raimondo at (304)-293-8708 or call the Office of Research Integrity \& Compliance at (304) 293-7073.

I willingly agree to be in this project.

Signature of Subject

Printed Name

Date

Time

The minor has had the opportunity to have questions addressed. The minor willingly agrees to be in the project.

Signature of Investigator or Co-Investigator

Printed Name

Date

Time 